\title{
Dyplomacja na peryferiach. „Specjalne kontakty” polsko-norweskie w latach 60. XX wieku
}

\author{
Diplomacy on the peripheries: Polish-Norwegian "special contacts" in the 1960s
}

\begin{abstract}
"Special contacts" developed by Norway and Poland during the years 1963-1968 may serve as a unique example of peripheral diplomacy. The sense of Polish initiatives such as the Gomułka Plan consisted not only in relaxing the political tension in Europe, but also on securing the western Polish border, which was not internationally recognized by the West. Hence, initially, political contacts between Oslo and Warsaw served as a way of exercising soft pressure on NATO countries to change their stance. However, they had other interesting aspects, too, such as promotion of Polish culture in Norway. It was 1968 that marked a final date of the "special contact." It was the anti-Semitic campaign that took place in Poland that year, rather than invasion of Czechoslovakia, that was a final reason for this ending.
\end{abstract}

Key words: Poland, Norway, Winiewicz, Boyesen, Oder-Neisse, international relations, NATO

Słowa klucze: Polska, Norwegia, Józef Winiewicz, Jens Boyesen, Odra-Nysa, polityka międzynarodowa, NATO

Gdy w 1963 roku w Oslo pojawił się młody bułgarski reżyser teatralny zafascynowany norweskim dramatem, stał się sensacją dnia, bohaterem gazet i rozmówcą wybitnych norweskich luminarzy kultury (Rem 2010: 143). Trudno o lepszy dowód na to, że w pierwszej połowie lat 60 . Norwegia pozostawała głuchą europejską prowincją. Nie tylko zresztą daleka była od trendów dominujących w kulturze światowej, ale też odgrywała minimalną rolę w polityce międzynarodowej zdominowanej przez zmagania supermocarstw. A jednak w tym samym czasie doszło do bezprecedensowego ożywienia kontaktów polsko-norweskich. Dlaczego dwa kraje usytuowane na peryferiach polityki międzynarodowej postanowiły nawiązać współpracę na rzecz - jak oficjalnie głoszono - „utrwalenia pokoju i odprężenia w świecie"?

Wzajemne stosunki polsko-norweskie układały się stosunkowo dobrze - jeśli zważyć na to, że oba kraje dzieliła żelazna kurtyna - już od połowy lat 40. 
(Denkiewicz-Szczepaniak 2006). Szczyt wzajemnej izolacji przypada na apogeum stalinizmu w początku lat 50., ale zasadnicza poprawa przyszła po Październiku. Przemiany, do jakich doszło w Polsce w 1956 roku, przyniosły nie tylko nowe kierownictwo partyjne i zasadnicze zmiany w praktyce rządzenia, lecz także stały się poważnym kapitałem w polityce zagranicznej. Jeszcze kilka lat po Październiku wprost mówili o tym w poufnych rozmowach politycy norwescy ${ }^{1}$. Skutkowało to tym, że „Norwegia pojawiała się jako partner chętny do rozmów z socjalistyczną Polską po roku [19]56"2. W ocenach polskich dyplomatów jednym z głównych powodów pchających Oslo do dialogu z Warszawą była chęć odegrania roli pomostu w złożonych relacjach Wschód - Zachód. Kontakty z Polską mogły stanowić jego przydatny element.

W tym kontekście za pierwszy istotniejszy impuls dla wzajemnych kontaktów można uznać Plan Rapackiego, przewidujący stworzenie strefy bezatomowej obejmującej Niemcy Zachodnie, Niemcy Wschodnie, Czechosłowację i Polskę. To wystąpienie polskiej dyplomacji z jesieni 1957 roku było próbą upieczenia kilku pieczeni przy jednym ogniu. Szło o wykorzystanie entuzjazmu, jaki na Zachodzie wzbudził polski Październik, do utrwalenia na forum międzynarodowym przekonania o posiadanym przez Warszawę szerszym marginesie politycznego manewru. Efektem miał być nie tylko wzrost prestiżu ekipy Gomułki, ale również pogłębienie istniejących „rozbieżności wśród członków NATO na tle stosunku do inicjatyw bloku wschodniego" (Pasztor 2003: 88). Wówczas jednak dialog polsko-norweski zawisł w próżni, bowiem pomimo zainteresowania Norwegów rozbrojeniowymi pomysłami szefa polskiego MSZ zostały one ostatecznie unisono odrzucone przez kraje NATO (Kłonczyński 2006: 233-252). Warto jednak podkreślić, że rząd norweski w 1957 roku stanął na stanowisku, iż nie będzie magazynował ładunków atomowych na swoim terytorium, i od tamtej pory konsekwentnie je podtrzymywał pomimo nacisków sojuszników (Skogrand 2006: 182-183). Ponadto polsko-norweska umowa o współpracy podpisana w grudniu 1958 roku umożliwiła rozwinięcie relacji naukowo-kulturalnych. Tym samym PRL stała się w tej sferze pierwszym partnerem Norwegii spośród krajów socjalistycznych.

W ostatnich dniach 1963 roku na wystąpieniu w Płocku Władysław Gomułka przedstawił tzw. Plan Gomułki zakładający zamrożenie zbrojeń jądrowych i termojądrowych na terytorium Polski, Czechosłowacji, NRD i RFN. W dwa miesiące później rząd PRL przedstawił krajom zachodnim oficjalne memorandum w tej sprawie (Łoś-Nowak 1989: 256-275) i spotkało się ono

\footnotetext{
${ }^{1}$ Archiwum Akt Nowych, KC PZPR, 237/XXII-1108, Rozmowa z Loebergiem, członkiem norweskiego parlamentu (Norweska Partia Pracy), 23.08.1960 r., k. 20.

2 Archiwum Ministerstwa Spraw Zagranicznych, Departament III, sygn. 28/71, w-10, Czy nowa polityka Norwegii wobec KDL?, [wrzesień 1966 r.].
} 
ponownie z zainteresowaniem Norwegów ${ }^{3}$ I choć pozostałe kraje NATO ponownie nie były zainteresowane, by wprowadzić w życie propozycje I sekretarza KC PZPR, to właśnie z początkiem 1964 roku rozpoczął się nadspodziewanie intensywny okres wzajemnych polsko-norweskich kontaktów, nie tylko zresztą politycznych ${ }^{4}$.

Skok jakościowy był dostrzegalny gołym okiem. We wrześniu 1965 roku odwiedził Oslo minister kultury Lucjan Motyka, a jego wizyta „miała przebieg bardzo pomyślny”5. W Norwegii z dużą satysfakcją odnotowywano wyraźne ożywienie wymiany kulturalnej (Halvorsen 1965a: 8-9), w rzeczywistości dość jednostronnej - ponieważ to głównie polscy twórcy przyjeżdżali nad fiordy. Warto odnotować między innymi występy muzyków: Barbary Hesse-Bukowskiej, Karola Stryji, Kwintetu Warszawskiego i Wandy Wiłkomirskiej ${ }^{6}$. Jeszcze ważniejsza była rola polskich twórców teatru, nierzadko zresztą narzekających na norweski prowincjonalizm. W Det Norske Teatret do wystawienia Procesu Kafki zaangażowano między innymi Henryka Tomaszewskiego i Krzysztofa Pankiewicza, jednak w ocenie polskich dyplomatów spektakl „wywołał szok w środowisku teatralnym norweskim, nieobytym z teatrem nowoczesnym" ". Nadto Polskę odwiedziła nienotowana wcześniej grupa norweskich dziennikarzy, czego owocem były poświęcone Polsce liczne publikacje na łamach ogólnokrajowej prasy. Jedynym poważniejszym tytułem, który odmówił nawiązania kontaktów z dyplomatami PRL, był konserwatywny Aftenposten ${ }^{8}$.

Kluczowym komponentem wzajemnych relacji pozostawały jednak kontakty dyplomatyczne. Wiceszef polskiego MSZ Józef Winiewicz odwiedzał Oslo w styczniu 1964 roku, w styczniu 1965 roku oraz na przełomie marca i kwietnia 1966 roku. Jego norweski odpowiednik Jens Boyesen rewizytował Polskę w czerwcu 1965 roku i była to jego pierwsza w życiu wizyta za żelazną kurtyną, co samo w sobie wydaje się symboliczne9. W końcu 1966 roku polscy dyplomaci oceniali, że „współpraca z norweskim MSZ jest b[ardzo]. dobra, do tego stopnia, iż [Norwegowie] uważali zawsze za potrzebne informować nas o ważniejszych zdarzeniach nas obchodzących (zwłaszcza po wizytach polityków NRF). Ten stan stosunków

\footnotetext{
3 AAN, KC PZPR, 237/XXII-1506, Kilka aktualnych problemów Norwegii, 15.05.1965 r., k. 185.

${ }^{4}$ AMSZ, Dep. III, sygn. 47/68, w-13, Notatka o pobycie delegacji ZG ZMS w Norwegii [maj 1965]; AMSZ, Dep. III, sygn. 46/68, w-9, Notatka z rozmowy z H. Pedersenem, 18.02.1965 r.

5 AMSZ, Dep. III, sygn. 46/68, w-9, Szyfrogram nr 11559 z Oslo, 21.09.1965 r.

${ }^{6}$ AMSZ, Dep. III, sygn. 47/68, w-13, Kultura i nauka polska w Norwegii, [początek 1965 r.].

7 AMSZ, Dep. III, sygn. 46/68, w-9, Ramowy plan działalności Ambasady PRL w Oslo na okres grudzień 65 r. - czerwiec 66 r., 19.11.1965 r.

${ }^{8}$ Ibid.

9 AMSZ, Dep. III, sygn. 47/68, w-13, Notatka ministra Józefa Winiewicza z rozmów z wiceministrem spraw zagranicznych Norwegii Jensem Boyesenem, 14.06.1965 r.
} 
kierownictwo norweskie zwykło określać jako 'modelowe stosunki między dwoma państwami obu ugrupowań”"10.

Przekonanie o wyjątkowości relacji Warszawa - Oslo znalazło odzwierciedlenie w publicystyce - w Norwegii zaczęto mówić o istnieniu „dialogu polsko-norweskiego” czy też „specjalnych kontaktów polsko-norweskich”. Natura tego dialogu była jednak specyficzna i wynikała tyleż z różnic w kulturze politycznej czy $\mathrm{w}$ temperamencie, co z nie w pełni samodzielnej roli politycznej odgrywanej przez oba kraje. Już w 1958 roku, gdy wiceminister Winiewicz nieoficjalnie pojawił się w Oslo, gospodarze poprosili go o utrzymanie w tajemnicy faktu nawiązania wzajemnych kontaktów (Winiewicz 1985: 554). Dyskrecja i powściągliwość ze strony Norwegów pozostawały normą również w kolejnych latach. Oto gdy w czerwcu 1965 roku, podsumowując wizytę wiceministra Boyesena nad Wisłą, Życie Warszawy napisało, że oba kraje zajmują analogiczne stanowisko wobec problemu wietnamskiego, wywołało to w Norwegii falę protestów. Prawicowy Morgenbladet atakował rząd za rozwój stosunków z krajami socjalistycznymi, które „wykorzystują go do swych celów propagandowych" przeciwko Niemcom Zachodnim i USA ${ }^{11}$, a wspomniany Aftenposten wzywał własny rząd do większej ostrożności, krytycznie oceniając, że „nawet najbardziej ostrożne próby ze strony małego państwa zachodniego w kierunku odprężenia poprzez bezpośredni kontakt z krajem wschodnim mogą być przedstawione jako skierowane przeciw USA”12. „Uważamy za pożyteczne kontynuowanie niezobowiązującego norwesko-polskiego dialogu” - odpowiadał krytykom prorządowy dziennik Arbeiderbladet. „Nie wiemy dziś, co konkretnego może on przynieść. Ale jesteśmy przekonani, że już sama dyskusja jest wkładem w zmiękczenie sztywnych linii podziału" (Polen og Morgenbladet 1965: 4) - puentował. Specyficzna to odpowiedź, gdy rządowe porte parole stwierdza, że trudno wskazać namacalne korzyści z politycznego dialogu z drugim państwem. Warto zatem zadać pytanie: co spowodowało, że stosunki polsko-norweskie rozkwitły z wielką mocą właśnie w pierwszej połowie lat 60.?

Dokumentacja Wydziału Zagranicznego KC PZPR pokazuje, że jeszcze w końcu lat 50. władze komunistyczne w Polsce przywiązywały dużą wagę do kontaktów z Norweską Partią Komunistyczną. Jej członkowie uznawani byli za członków ogólnoświatowej rodziny partii komunistycznych i robotniczych, stąd też między innymi brali udział w Zjazdach PZPR ${ }^{13}$. Jednocześnie NPK chętnie dzieliła się z polskimi towarzyszami swoimi - niezwykle krytycznymi - ocenami rządzącej

${ }_{10}$ AMSZ, Dep. III, sygn. 27/71, w-8, Pilna notatka Kazimierza Dorosza na temat aktualnej polityki zagranicznej Norwegii, 17.12.1966 r.

${ }^{11}$ AMSZ, Dep. III, sygn. 47/68, w-13, Claris nr 263 z 18 czerwca 1965 r., 19.06.1965 r.

12 Ibid.

${ }_{13}$ AAN, KC PZPR, 237/XXII-1108, Notatka dot. delegacji Komunistycznej Partii Norwegii, 21.03.1959 r., k. 1-2. 
socjaldemokracji1 ${ }^{14}$. Tymczasem Norweska Partia Pracy w latach 1945-1965 pozostawała hegemonem sceny politycznej w kraju fiordów, a jej wieloletni lider Einar Gerhardsen zyskał sobie wśród rodaków miano „ojca narodu”. To szef norweskiego MSZ Halvard Lange był jednym z pomysłodawców NATO, a następnie realizatorem proamerykańskiej polityki zagranicznej, czemu zresztą w znacznej mierze przysłużyło się sąsiedztwo z ZSRR (Nuckowska-Cherek 2015: 268-280). Podjęcie dialogu $\mathrm{z}$ rządem socjaldemokratycznym w Norwegii wymagało od kierownictwa PZPR przewartościowania polityki: nad ideologią prymat musiał wziąć pragmatyzm. Sytuację ułatwiał fakt, że Komunistyczna Partia Norwegii była nieliczna (na przełomie lat 1964-1965 liczyła raptem 5 tys. członków ${ }^{15}$ ), a w kolejnych wyborach ponosiła klęskę za klęską ${ }^{16}$. Nadto jeszcze pozycję NPK w gronie światowych partii komunistycznych podkopywała niejednoznaczna postawa zajmowana przezeń wobec sporu chińsko-radzieckiego, co wywoływało rozczarowanie Moskwy ${ }^{17}$. W efekcie jesienią 1965 roku polscy dyplomaci, charakteryzując kierownictwo NPK, pisali, iż ,jak twierdzą przeciwnicy, zajmuje zacofane, sekciarskie stanowisko w sprawach stosunku do Norweskiej Partii Pracy" ${ }^{18}$. Choć autor notatki zastrzegał, że jedynie referuje krytyczną ocenę, trudno pozbyć się wrażenia, że tego rodzaju pogląd w Warszawie podzielano. Stanowiło to czytelną miarę ewolucji postawy polskiego kierownictwa wobec norweskich towarzyszy.

Pragmatyczna postawa polskiego kierownictwa miała konkretne przyczyny i wynikała przede wszystkim z hierarchii priorytetów polskiej polityki zagranicznej. W początku lat 60. na jej szczycie niezmiennie znajdowało się zyskanie międzynarodowego uznania dla zachodniej granicy PRL na Odrze i Nysie Łużyckiej. Tak Plan Rapackiego, jak i Plan Gomułki były wszak obliczone na to, by Niemcy Zachodnie nie otrzymały dostępu do broni atomowej, a co za tym idzie, by w przyszłości nie mogły potencjalnie wykorzystać jej do siłowego przywrócenia swoich granic z 1937 roku. W dalszej perspektywie popularyzacja Polski i jej polityki w Norwegii miała zatem na celu pozyskanie polityków i opinii publicznej dla idei uznania polskiej granicy zachodniej. „Hamowanie lub uniemożliwianie postępu w odprężeniu między Wschodem a Zachodem" ${ }^{19}$ było głównym zarzutem pod adresem RFN, konsekwentnie formułowanym przez polskich gości nad fiordami.

\footnotetext{
${ }^{14}$ Ibid., Socjaldemokracja norweska (opracowanie KC KPN z 1958 r.), 21.03.1959 r., k. 7-18.

15 AAN, KC PZPR, 237/XXII-1506, Komunizm w Skandynawii (kryzys w ruchu komunistycznym), wiosna 1966 r., k. 40.

${ }_{16}$ AAN, KC PZPR, 237/XXII-1108, Norweska lewica robotnicza po wyborach komunalnych, 30.09.1963 r., k. 255.

${ }^{17}$ Ibid., Uwagi o stanowisku Komunistycznej Partii Norwegii w sprawie podstawowych zagadnień sytuacji międzynarodowej i międzynarodowego ruchu robotniczego, 12.01 .1963 r., k. 233. ${ }_{18}$ AMSZ, Dep. III, sygn. 46/68, w-9, Notatka dot. sytuacji w Komunistycznej Partii Norwegii, $4.10 .1965 \mathrm{r}$.

${ }^{19}$ Ibid., Działalność propagandowa Ambasady PRL - w okresie jesień '64 - jesień '65, 8.10.1965 r.
} 
Miało to swoje znaczenie przede wszystkim dlatego, że Norwegia nie była państwem neutralnym. „Czy [...] jeszcze możemy uważać Norwegię za 'słabe ogniwo' NATO?"20 - pisał we wrześniu 1966 roku w liście do zwierzchników ambasador PRL w Oslo. Kazimierz Dorosz z brutalną szczerością wyraził w ten sposób drugą polską motywację. Norwegia wydawała się Polakom najlepszym kandydatem na adwokata sprawy polskiej na forum Sojuszu Północnoatlantyckiego.

„Podobnie jak inne państwa skandynawskie Norwegia marginesowo interesuje się problematyką powszechnego i całkowitego rozbrojenia, koncentrując swoją uwagę na rozwiązaniach częściowych i regionalnych"21 - odnotowywali polscy dyplomaci jesienią 1965 roku. Czy jednak gotowość do popularyzacji idei rozbrojenia była rzeczywiście głównym powodem, który pchnął norweską dyplomację do intensywniejszych kontaktów z Polakami? Norwescy politycy nie byli naiwnymi pięknoduchami. Polityczna gra pod nazwą „dialog z Polską” miała również i dla nich swoją wymierną wartość.

Nie jest przypadkiem, że ożywienie w relacjach Oslo - Warszawa odnotowywane jest już w roku 1963 (Romański 2014: 166). W końcu sierpnia tego roku, po osiemnastu latach nieprzerwanych rządów socjaldemokratycznych, upadł gabinet Einara Gerhardsena. Bezpośrednią przyczyną było secesja grupy skupionej wokół tygodnika Orientering, sytuującej się na lewicy Norweskiej Partii Pracy, która utworzyła Socjalistyczną Partię Ludową. Socjaldemokratom do utrzymania większości zabrakło głosów dwóch rozłamowców z NPP. W konsekwencji drugim powojennym premierem Norwegii został konserwatysta John Lyng, stając na czele koalicyjnego rządu. Jego gabinet nie przetrwał jednak nawet miesiąca, bo członkowie SPL zmienili zdanie, dzięki czemu gabinet ponownie sformował Gerhardsen. Ten ostatni zrozumiał ostrzeżenie i postanowił wyciągnąć z niego wnioski. Skonstatował, że różnice między SPL a NPP sprowadzały się w znacznej mierze do polityki międzynarodowej: secesjoniści pragnęli zbliżenia z krajami komunistycznymi i rozluźnienia więzi z USA ${ }^{22}$. Dialog z Polską był tu znakomitym rozwiązaniem: nie dość, że był niezobowiązujący (o czym wszak otwarcie pisano w prasie!), to jeszcze Polacy sami byli zainteresowani zacieśnianiem więzi. Nie bez znaczenia były względy praktyczne: ani Czechosłowacja, ani Węgry nie miały w owym czasie ambasadora w norweskiej stolicy, natomiast Jugosławia - wysoko ceniona w Oslo - pozostawała poza Układem Warszawskim.

„Stosunki norwesko-polskie są modelem właściwych stosunków dwu państw należących do różnych ugrupowań i o różnych ustrojach politycznych"23 - mówił

${ }^{20}$ AMSZ, Dep. III, sygn. 27/71, w-8, List Kazimierza Dorosza do Antoniego Szymanowskiego, 9.09.1966 r.

${ }^{21}$ AMSZ, Dep. III, sygn. 47/68, w-13, Norwegia wobec problemów rozbrojenia, jesień 1965 r.

${ }^{22}$ AMSZ, Dep. III, sygn. 46/68, w-9, Pilna notatka o pobycie w Polsce Knuta Loefsnesa,

17.11.1965 r.

${ }^{23}$ AAN, KC PZPR, 237/XXII-1506, Kilka aktualnych problemów Norwegii, 15.05.1965 r., k. 185 . 
w maju 1965 roku w poufnej rozmowie dyrektor generalny departamentu politycznego norweskiego MSZ. Świadczyło to o wyraźnym zadowoleniu, jakie panowało w Oslo w związku z kontaktami z Polską. Jak oceniał polski dyplomata, „dopóki rząd norweski, obojętnie socjaldemokratyczny czy nie, będzie zmuszony przekonywać swą opinię społeczną, iż 'udział w NATO nie ogranicza swobody politycznej Norwegii', dopóty będzie manifestował chęć zbliżenia z krajami socjalistycznymi. Szczególnie z Polską" ${ }^{24}$. Rzeczywiście, im bliżej było do wyborów parlamentarnych zaplanowanych na wrzesień tego roku, tym chętniej socjaldemokraci korzystali $\mathrm{z}$ tego atutu. Świadczyła o tym nie tylko wspomniana wizyta wiceministra Boyesena czy nieoficjalne przyjęcie przez premiera Gerhardsena zaproszenia do odwiedzenia Polski, ale także wywiad, jakiego ten ostatni udzielił polskiej telewizji ${ }^{25}$, czy fakt, iż Arbeiderbladet wysłał do Warszawy stałego korespondenta, którym został Dag Halvorsen ${ }^{26}$. W ocenie polskich dyplomatów „sprawa dialogu z Polską stała się jednym z głównych elementów składowych akcji wyborczej Norweskiej Partii Pracy i zgodnie $\mathrm{z}$ informacjami naszej ambasady omawiana jest na zebraniach przedwyborczych wszystkich szczebli. Prowadzi to siłą rzeczy do korzystnego dla nas wzrostu zainteresowania norweskiej opinii publicznej problematyką planów polskich"27.

Nad Wisłą podejmowano próby dyskontowania propolskich nastrojów w Norwegii. Najważniejszą był opublikowany w lipcu 1965 roku na łamach Polityki tekst Daniela Passenta, w którym autor, analizując ożywienie polityczne w Norwegii, dostrzegał „nowe elementy” w norweskiej polityce zagranicznej na rzecz odprężenia (Passent 1965: 5). Owe „nowe elementy” uchwycone przez warszawskiego dziennikarza były niewątpliwie przedyskutowane z urzędnikami polskiego MSZ. Można sądzić, że tekst był próbą skłonienia Norwegów do bardziej konkretnych deklaracji, co oznaczało chęć wykroczenia poza „niezobowiązujący” charakter kontaktów polsko-norweskich. Tak też zinterpretowano to w Oslo i w końcu lipca z opinią Passenta polemizowało Arbeiderbladet (Halvorsen 1965b: 8), a dzień później także Aftenposten ${ }^{28}$. Gdy w kilka dni później organ NPP opublikował list czytelnika, który pytał, czy nie czas już uznać granicę na Odrze i Nysie, zamieszczono następującą odpowiedź: „Rząd norweski dawał już wyraz swemu stanowisku w tej sprawie, tj. że uważa granicę na Odrze i Nysie za trwałą. Nie może jej jednak uznać formalnie aż do czasu przyszłej konferencji pokojowej" (Tøværet i Europa 1965: 8). Odpowiedź ta wywołała natychmiastową interwencję ambasady zachodnioniemieckiej ${ }^{29}$.

${ }^{24}$ AMSZ, Dep. III, sygn. 47/68, w-13, Notatka z rozmowy z Thorvaldem Stoltenbergiem (MSZ) z 16.07.1965 r., 3.08.1965 r.

${ }^{25}$ Ibid., Wywiad Einara Gerhardsena dla Dziennika Telewizyjnego, [18.06.1965 r.].

${ }^{26}$ AMSZ, Dep. III, sygn. 46/68, w-9, Działalność propagandowa Ambasady PRL - w okresie jesień '64 - jesień '65, 8.10.1965 r.

${ }^{27}$ AMSZ, Dep. III, sygn. 47/68, w-13, Norwegia wobec problemów rozbrojenia, [jesień 1965 r].

${ }_{28}$ AMSZ, Dep. III, sygn. 47/68, w-13, Pismo Szymanowskiego do Winiewicza, 14.08.1965 r.

${ }^{29}$ Ibid. 
W efekcie, jak się wydaje, tak Polacy, jak i Norwegowie osiągnęli swoje cele. Ci pierwsi uzyskali potwierdzenie intencji rządu socjaldemokratycznego względem granicy zachodniej, a drudzy - grając na nosie sojusznikom z Bonn - dali wyborcom świadectwo swojej niezależności.

„ZSRR nie jest 'partnerem' do kontaktu dla małej Norwegii. Takiego partnera natomiast widzą w Polsce, tym bardziej, iż odpowiada im często linia działania dyplomacji polskiej, jak szukanie częściowych rozwiązań w dziedzinie rozbrojenia itp." ${ }^{30}$ - donosili z Oslo polscy dyplomaci w lutym 1966 roku. Było to już kilka miesięcy po wyborach parlamentarnych, które zakończyły się porażką socjaldemokracji i sformowaniem koalicyjnego gabinetu przez Pera Bortena, działacza Partii Centrum. Karta „szczególnego dialogu” z Polską nie wystarczyła zatem socjaldemokratom do tego, by uzyskać większość w Stortingu. Między listopadem 1965 roku a styczniem 1966 roku Warszawa oczekiwała na deklaracje co do tego, czy nowy koalicyjny rząd norweski podtrzyma chęć kontynuowania dotychczasowych relacji. I doczekała się - prorocze okazały się słowa wiceministra Boyesena wypowiedziane w czasie wizyty w Warszawie: „Polityka norweska nie ulegnie żadnym istotnym zmianom bez względu na wynik wyborów, nie jest to bowiem polityka partyjna, ale narodowa, posiadająca poparcie całego Stortingu" ${ }^{\prime 31}$. Utylitarny charakter kontaktów polsko-norweskich był jasny dla obu stron. „Szereg osobistości dobrze zorientowanych i szczerze przyjaznych stosunkom z Polską doradza bardzo poważnie, aby 'oswoić' (wyrażenie ich) niektórych znaczniejszych działaczy nowej konstelacji rządzącej ze współistnieniem, i to w pierwszym rzędzie z Polską, drogą zaproszenia ich do naszego kraju"32 - pisał ambasador PRL w liście do wiceministra Winiewicza. Rzeczywiście, w 1966 roku takich rozmów nie zabrakło, między innymi zaproszono nad Wisłę lidera norweskich liberałów Gunnara Garbo. Po krótkiej pauzie ruszyli na północ także Polacy.

W lutym 1966 roku w Oslo gościł redaktor naczelny Polityki Mieczysław Rakowski. Zaproszenie było konsekwencją dyskusji prasowej pomiędzy kierowanym przez niego tygodnikiem a Arbeiderbladet z połowy $1965 \mathrm{roku}^{33}$. „Oczekiwany jest $\mathrm{z}$ dużym zainteresowaniem, zwłaszcza sprawy niemieckie w polskim ujęciu. Chcą go zaprowadzić do czołowych polityków i działaczy"34 - anonsowali planowaną wizytę polscy dyplomaci. Nadano jej rzeczywiście zaskakująco wysoką rangę, bowiem Rakowski spotkał się z ważnymi osobistościami politycznymi, w tym z szefem

${ }_{30}$ AMSZ, Dep. III, sygn. 27/71, w-8, Stanowisko nowego rządu norweskiego wobec stosunków polsko-norweskich, 3.02.1966 r.

${ }^{31}$ AMSZ, Dep. III, sygn. 47/68, w-13, Notatka ministra Józefa Winiewicza z rozmów z wiceministrem spraw zagranicznych Norwegii Jensem Boyesenem, 14.06.1965 r.

32 AMSZ, Dep. III, sygn. 46/68, w-9, List Kazimierza Dorosza do Józefa Winiewicza, 14.01.1966 r.

${ }^{33}$ Ibid., Szyfrogram nr 10420 z Oslo. Dorosz do Milnikiela, 26.08.1965 r.

34 AMSZ, Dep. III, sygn. 46/68, w-9, Plan orientacyjny sezonu styczeń - czerwiec 1966 r. w dziedzinie stosunków polsko-norweskich tak politycznych, jak kulturalnych i innych, koniec $1965 \mathrm{r}$. 
norweskiego MSZ (Polsk redaktør i Studentersamfundent i kveld 1966: 3; Rakowski 1966: 5), a także wygłosił odczyt o polskiej polityce zagranicznej w Oslo Studentersamfundet, gdzie przed nim występowali między innymi Anastas Mikojan, Harold Macmillan czy Adam Rapacki ${ }^{35}$. Ponadto w Arbeiderbladet opublikowano obszerny wywiad z polskim gościem, poświęcony stosunkom polsko-niemieckim (Halvorsen 1966: 3). „Przyjmowano mnie bardzo dobrze, podkreślano zainteresowanie Polską i częściowo moją osobą" ${ }^{36}$ - odnotował w swoim dzienniku Rakowski.

Poglądy przedstawiane przez naczelnego Polityki wywoływały ogromne zainteresowanie, zwłaszcza gdy zestawić je z kostycznym sposobem uprawiania polityki przez polityków z bloku komunistycznego. „Przedstawiane było to jako nowy komunizm, typu socjaldemokratycznego" ${ }^{37}$ - wspominał w rozmowie ze mną Józef Wiejacz. Polegał on raczej na formie, aniżeli na treści poglądów gościa; na większej otwartości, gotowości do dialogu, ciekawości świata i stosowaniu innego języka stanowczego, ale pozbawionego arogancji i agresji. Pamiętajmy, że w ówczesnym Oslo, jak na europejską miarę mieście dość prowincjonalnym, przyjazd gości z Polski stanowił godne odnotowania wydarzenie. Dotyczyło to zresztą nie tylko Rakowskiego, ale także wspomnianych wcześniej twórców kultury. W początku 1966 roku ambasador PRL w Oslo z dużą satysfakcją odnotowywał, że „w stosunkach kulturalnych, ograniczonych siłą rzeczy niezbyt dużymi zainteresowaniami kulturalnymi społeczeństwa norweskiego, wybija się coraz bardziej ciekawy czynnik, mianowicie szukanie inspiracji artystycznej u nas" ${ }^{\prime 3}$. Ale na tym nie koniec. W latach 1965-1966 w norweskiej stolicy gościli także między innymi wybitny prawnik Manfred Lachs, przewodniczący Stołecznej Rady Narodowej Janusz Zarzycki i marksistowski filozof Adam Schaff. Wszyscy oni zaliczali się do grona intelektualistów, w owym czasie reprezentując poglądy stosunkowo „liberalne”, jak na warunki gomułkowskiego PRL - prawdziwie reformatorskie. Komunistyczna Polska, jaka wyłaniała się z ich wypowiedzi, dawała się lubić: jej argumentów można było wysłuchać, zgodzić się z nimi, mimo że goście przybywali z kraju położonego po drugiej stronie żelaznej kurtyny.

Powtórzmy raz jeszcze, że dla Warszawy kluczowe znaczenie miało popularyzowanie Polski jako takiej, aby dzięki temu lepiej słyszalne było stanowisko polskie w sprawach bezpieczeństwa europejskiego (z fundamentalną rolą granicy na Odrze i Nysie). Dla polskiej dyplomacji w połowie lat 60 . nie był to z pewnością

\footnotetext{
35 AMSZ, Dep. III, sygn. 47/68, w-13, List Antoniego Szymanowskiego do Manfreda Lachsa, $6.11 .1964 \mathrm{r}$.

${ }^{36}$ Hoover Institution Archives, Mieczysław F. Rakowski papers, Box 1, Dzienniki Polityczne, Tom 15, k. 14 (6.03.1966 r.).

${ }^{37}$ Relacja Józefa Wiejacza, 17.10.2016 r., w zbiorach autora.

38 AMSZ, Dep. III, sygn. 46/68, w-9, Pilna notatka z rozmowy z ambasadorem Norwegii, 7.01.1966 r.
} 
najważniejszy dyplomatyczny front, ale zważywszy na ograniczone środki, jakimi dysponowała, zaangażowanie w kontakty z Norwegami były udanym przedsięwzięciem. Z punktu widzenia wielkiej polityki największym polskim sukcesem było oświadczenie szefa norweskiego MSZ Halvarda Lange z czerwca 1964 roku. „Z punktu widzenia formalnego i prawnego sprawa wygląda tak, że granice niemieckie zostaną ustalone drogą rokowań pokojowych - jest to punkt widzenia czterech mocarstw, co do którego nigdy nie było różnicy zdań. Je d n a k $\mathrm{n}$ i e są realistami ci, którzy mogą sobie wyobrażać jakieś zmiany w istniejącej de facto sytuacji dokoła zewnętrznych granic niemieckich [podkreślenie moje - M.P.], będących rezultatem drugiej wojny światowej” 39 - powiedział Lange w czasie debaty w Stortingu. „Formuła Langego" została potwierdzona przez jego następcę Johna Lynga w końcu października $1966 \mathrm{roku}^{40}$. Dalszych badań wymagają również same w sobie niezwykle interesujące społeczne i kulturalne aspekty kontaktów polsko-norweskich w latach 60. Warto podkreślić, że dla ich rozwoju niemałe znacznie miała zręczność polskiej ambasady, która potrafiła dostroić przekaz propagandowy do potrzeb lokalnych odbiorców. „Materiały o wojnie, obozach koncentracyjnych itd. nie spełniają tu roli, jaką się być może w kraju z nimi wiąże z powodu czysto ludzkich właściwości - Norwegowie chcą zaoszczędzić sobie przykrych wspomnień i akcent wolą kłaść na stronę pozytywną zagadnienia" ${ }^{\prime 11}$ - podkreślano w październiku 1965 roku, korygując oceny centrali.

Niemcy Zachodnie najpewniej nieprzychylnym okiem patrzyły na rozwój kontaktów Oslo - Warszawa i próbowały niwelować jej skutki. Tak można było interpretować podaną przez Arbeiderbladet informację o tym, że rozgłośnia radiowa Deutschlandsfunk w Kolonii rozpoczęła w dniu 22 listopada 1965 roku nadawanie regularnego programu w języku norweskim ${ }^{42}$. Na dłuższą metę poważniejszym problemem była jednak postawa norweskich elit politycznych wobec RFN. Einar Gerhardsen był „ostatnim premierem kraju Europy zachodniej, który oficjalnie wizytował RFN"43, do czego doszło wiosną 1965 roku po długotrwałym zwlekaniu. Brak sympatii Norwegów do Niemców był w Bonn rzeczą doskonale znaną, do tego stopnia, że gdy Ludwig Erhard pojawił się Oslo w kolejnym roku, sam poprosił o możliwie jak najskromniejszą oprawę wizyty. O ile jednak Erhard, chrześcijański demokrata, nie był ceniony w norweskiej stolicy, to zupełnie inaczej

39 AMSZ, Dep. III, sygn. 47/68, w-13, Aktualny stan stosunków polsko-norweskich na tle norweskiej polityki zagranicznej, [21.04.1965 r.].

40 AMSZ, Dep. III, sygn. 28/71, w-8, Debata zagraniczna w norweskim Stortingu (27-28.10. 1966 r.), $10.11 .1966 \mathrm{r}$.

${ }^{41}$ AMSZ, Dep. III, sygn. 46/68, w-9, Działalność propagandowa Ambasady PRL - w okresie jesień '64 - jesień '65, 8.10.1965 r.

42 AMSZ, Dep. III, sygn. 47/68, w-13, Notatka prasowa ambasady w Oslo, 4.12.1965 r.

${ }^{43}$ AMSZ, Dep. III, sygn. 46/68, w-9, Wizyta premiera Einara Gerhardsena w RFN, 3.04.1965 r. 
było w przypadku socjaldemokratów niemieckich ${ }^{44}$, przede wszystkim Willy’ego Brandta (Jarząbek 2011: 100-101).

Ten ostatni, wyemigrowawszy z Niemiec po dojściu Hitlera do władzy, wiele lat spędził właśnie w Norwegii, współpracując z lokalnym ruchem robotniczym, i był tu ogromnie szanowany. Ambasada PRL już w październiku 1966 roku odnotowywała, że trzeba było aktywnie działać, argumentując, że odpowiedzialność za zły stan stosunków polsko-zachodnioniemieckich zależy od postawy Bonn, bowiem „wśród części tut.[ejszych] socjaldemokratów pod wpływem [Willy’ego] Brandta i [Helmuta] Schmidta były tendencje do przerzucania odpowiedzialności za ten stan na nas”45. Dezorientację budziły obserwacje, że „ktoś szerzy pomiędzy norweskimi politykami, dziennikarzami itd. informacje, jakoby Polacy stawiali żądania 'niemożliwe', w miarę jak zbliża się sprawa rozwiązania problemu granicy na Odrze i Nysie" ${ }^{\prime 4}$. Takie były konsekwencje przyjęcia przez polską dyplomację formuły głoszącej, że „zbliżenie [Warszawy] z RFN powinno iść w parze z normalizacją przez państwa zachodnie stosunków z NRD” (Jarząbek 2011: 66). Była to dla większości Norwegów postawa niezrozumiała i niebudząca ich sympatii. Gdy jesienią 1966 roku powstał w Bonn rząd wielkiej koalicji CDU -SPD, a Brandt został wicekanclerzem i szefem zachodnioniemieckiej dyplomacji, sytuacja skomplikowała się jeszcze bardziej. Dotychczasowe wpływy gospodarcze RFN w Skandynawii, z którymi Polska w oczywisty sposób nie mogła konkurować, zostały wsparte działalnością charyzmatycznego i popularnego polityka. „Specjalny kontakt polsko-norweski” mógł tego nie wytrzymać.

Nie było to zresztą jedyne zagrożenie dla bliskich kontaktów Polski i Norwegii. We wrześniu 1966 roku ambasada w Oslo donosiła do centrali, że wśród norweskich socjaldemokratów upowszechnia się opinia, iż należy „przesunąć swe zainteresowania z 'kanału' polskiego na Czechosłowację, Węgry i Rumunię" ${ }^{47}$. Jednym powodem było wspomniane już usztywnienie się Warszawy wobec Bonn i problemu niemieckiego, podczas gdy pozostałe kraje uznawano za znacznie bardziej elastyczne w tej kwestii. Co ciekawe, dla Norwegów znaczenie miała mieć wewnętrzna polityka PRL: „We wzmiankowanych trzech krajach wschodnich zachodzą znacznie ciekawsze procesy ekonomiczne niż w Polsce, gdzie dziedzina eksperymentu ekonomicznego uległa zahamowaniu"48 (Koryś, Tymiński 2016: 125-130). Rzeczywiście, tak w Czechosłowacji, jak i na Węgrzech podejmowano próby reform ekonomicznych (Przeperski 2012: 229), a Rumunia - nad którą wła-

${ }_{44}$ AMSZ, Dep. III, sygn. 46/68, w-9, Notatka z rozmowy z dyplomatą jugosłowiańskim w Oslo, 23.06.1965 r.

${ }^{45}$ AMSZ, Dep. III, sygn. 27/71, w-8, Depesza ambasadora Dorosza z Oslo, 24.10.1966 r.

${ }^{46}$ Ibid., Depesza ambasadora Dorosza z Oslo, 29.10.1966 r.

47 AMSZ, Dep. III, sygn. 28/71, w-10, Czy nowa polityka Norwegii wobec KDL?, [wrzesień $1966 \mathrm{r}]$.

${ }^{48}$ Ibid. 
dzę dopiero co objął Nicolae Ceaușescu - sposobiła się do dyplomatycznego uznania Niemiec Zachodnich. Na tym tle gomułkowska Polska przeżywająca rosnące kłopoty gospodarcze i rozrywana walkami wewnątrzpartyjnymi stawała się coraz mniej atrakcyjnym partnerem. W dziesięć lat po Październiku niewiele zostało z dawnego czaru Gomułki i jego polityki. Na płaszczyźnie krajowej udowodniły to represje wobec uczestników zebrania na Uniwersytecie Warszawskim 21 października 1966 roku; w sferze stosunków międzynarodowych można to dostrzec choćby po słabnięciu kontaktów polsko-norweskich.

„Znakomita większość spraw w naszym obrocie dwustronnym była i jest podejmowana $\mathrm{z}$ inicjatywy strony polskiej"49 - stwierdzali dyplomaci polscy w lutym 1965 roku. To samo można powiedzieć o całym okresie ożywienia w relacjach Warszawa-Oslo. W raportach do centrali wiązano to niekiedy ze specyficzną mentalnością dyplomatów norweskich, kiedy indziej zaś - jak sądzę bardziej zasadnie - z obawami gospodarzy przed reakcją innych państw NATO. Z punktu widzenia politycznego Polska nie mogła w Oslo osiągnąć niczego więcej ponad „formułę Langego", dalej idące deklaracje musiały być konsekwencją porozumienia polsko-zachodnioniemieckiego. Tymczasem począwszy od jesieni 1966 roku niechętne nastawienie Warszawy do zbliżenia z Bonn wywoływało w Norwegii zdumienie, podmywając - i tak dość wątłe - fundamenty „specjalnych kontaktów” z Polską. Pozostaje natomiast sprawą osobną, czy PRL nie mogła utrwalić swoich wpływów w sferze kultury, które w latach 60 . rozwijały się imponująco, stanowiąc niepoślednie świadectwo poziomu polskiego teatru czy muzyki.

Jest prawdą, że ostateczny cios „specjalnym kontaktom” z Polską zadała interwencja wojsk Układu Warszawskiego w Czechosłowacji w sierpniu 1968 roku. Uzmysłowiła ona Norwegom, że niezależność Polski wobec ZSRR jest iluzoryczna, co samo w sobie podważało sens jakiegokolwiek politycznego dialogu z PRL. Trzeba jednak pamiętać, że pozytywny obraz Polski w Skandynawii został zrujnowany na skutek agresywnej kampanii antysemickiej lat 1967-1968. „Od czasu wydarzeń marcowych w Polsce prasa tutejsza poświęca mniej niż dawniej uwagi kulturze polskiej, jak również problemom rozwoju gospodarczego w naszym kraju" - donosił ambasador w Oslo do centrali w lipcu 1968 roku. „Antypolska propaganda bazująca na oskarżeniach o antysemityzm wyrządziła nam pewne szkody w opinii norweskiej, ale nie wydaje się, by miały one charakter trwały" ${ }^{50}$. W rzeczywistości szkody okazały się niepowetowane. Jak odnotowywał Mieczysław Rakowski: „Norwegowie z obrzydzeniem przyjęli naszą walkę przeciwko 'syjonizmowi'”51. Pozytywne efekty promocji Polski i polskiej kultury zostały skutecznie przysłonięte przez antysemicką nagonkę.

${ }^{49}$ AMSZ, Dep. III, sygn. 46/68, w-9, Notatka z rozmowy z H. Pedersenem, 18.02.1965 r.

${ }^{50}$ Ibid., List M. Łobodycza do Dyrektora Departamentu III MSZ, 6.08.1968 r.

${ }^{51}$ HIA, Mieczysław F. Rakowski papers, Box 2, Dzienniki Polityczne, Tom 30, k. 14, (2.10.1970 r.). 
Bibliografia

Denkiewicz-Szczepaniak, E. (2006). Polsko-norweskie kontakty handlowe w latach 1945-1949. Dzieje Najnowsze 38 (4): 109-122.

Halvorsen, D. (1965a). Samarbeid med. Øst-Europa. Arbeiderbladet, 16 marca 1965: 8-9.

Halvorsen, D. (1965b). Tøvær i Norge. Arbeiderbladet, 30 lipca 1965: 8.

Halvorsen, D. (1966). Ikke hat - men mistillit. Arbeiderbladet, 15 lutego 1966: 3.

Jarząbek, W. (2011). Polska Rzeczpospolita Ludowa wobec polityki wschodniej Republiki Federalnej Niemiec w latach 1966-1976. Wymiar dwustronny i międzynarodowy. Warszawa: ISP PAN.

Kłonczyński, A. (2006). Norwegia wobec planu Rapackiego w latach 1957-1960. W: J. Szymański (red.). Polska - Norwegia 1905-2005. Gdańsk: Wydawnictwo Uniwersytetu Gdańskiego, s. $233-252$.

Koryś, P. i M. Tymiński. (2016). Od socjalizmu do socjalizmu. Koncepcje reform gospodarczych w PRL po wybuchach społecznych w 1956 i 1980 r. Dzieje Najnowsze 48 (4): 125-140.

Łoś-Nowak, T. (1989). Polskie inicjatywy w sprawie broni nuklearnej w Europie Środkowej 19571964. Wrocław: Uniwersytet Wrocławski.

Nuckowska-Cherek, K. (2015). Kierunki polityki Norwegii wobec Niemiec w latach 1945-1955. W: P. Pleskot (red.). Wina i kara. Społeczeństwa wobec rozliczeń zbrodni popetnionych przez reżimy totalitarne w latach 1939-1956. Warszawa: Instytut Pamięci Narodowej, s. 268-280.

Pasztor, M. (2003). Francja i Wielka Brytania wobec polskich koncepcji rozbrojeniowych 19571964. Dzieje Najnowsze 35 (1): 85-111.

Przeperski, M. (2012). Historia pewnego przystosowania. Węgrzy lat sześćdziesiątych w raportach Departamentu Badania Słuchalności Radia Wolna Europa. W: T. Kozłowski i J. Olaszek (red.). Opozycja i opór społeczny w Polsce po 1956 roku. T. 1. Warszawa: Instytut Pamięci Narodowej, s. 219-239.

Passent, D. (1965). Odwilż w Norwegii. Polityka 27: 5.

Polen og Morgenbladet. Arbeiderbladet, 17 czerwca 1965: 4.

Polsk redaktør i Studentersamfundent i kveld. Friheten, 15 lutego 1966: 3.

Rakowski, M.F. (1966). Dwa tygodnie u północnych sąsiadów. Polityka 11: 5.

Rem, T. (2010). Født til frihet. En biografi om Jens Bjørneboe. B. 2. Oslo: Cappelen Damm.

Romański, M. (2014). Norwegia wobec Bloku Wschodniego na tle wydarzeń roku 1968 w Czechosłowacji. Acta Universitatis Lodziensis. Folia Historica 93: 161-170.

Skogrand, K. (2006). Zimna wojna a norweska polityka atomowa (1945-1970). W: E. Denkiewicz-Szczepaniak i O.K. Grimes (red.). Norwegia - Polska Przeszłość i teraźniejszość. Toruń: Wydawnictwo Firet Jan Dokurno, s. 181-190.

Tøværet i Europa. Arbeiderbladet, 4 sierpnia 1965: 8.

Winiewicz, J. (1985). Co pamiętam z długiej drogi życia. Poznań: Wydawnictwo Poznańskie. 